\title{
Effects of intravenous neuropeptide $Y$ on insulin secretion and insulin sensitivity in skeletal muscle in normal rats
}

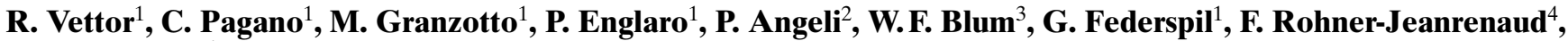 \\ B. Jeanrenaud ${ }^{4}$ \\ ${ }^{1}$ Endocrine-Metabolic Laboratory, Institute of Medical Semiotics, University of Padua, Italy \\ ${ }^{2}$ Department of Clinical and Experimental Medicine, University of Padua, Italy \\ ${ }^{3}$ Lilly Deutschland, Bad Homburg and University Children's Hospital, Giessen, Germany \\ ${ }^{4}$ Metabolic Research Laboratory, Department of Medicine, University of Geneva, Switzerland
}

\begin{abstract}
Summary Intracerebroventricular administration of neuropeptide $\mathrm{Y}$ to normal rats induces a syndrome characterised by obesity, hyperinsulinaemia, insulin resistance and over expression of the adipose tissue $o b$ gene. Little is known about the effect of circulating neuropeptide $\mathrm{Y}$ on glucose metabolism, insulin secretion and leptin. We therefore aimed to evaluate the effect of an intravenous infusion of neuropeptide $\mathrm{Y}$ on glucose disposal, endogenous glucose production, whole body glycolytic flux, and glucose storage as assessed during euglycaemic hyperinsulinaemic clamp. In addition, the insulin-stimulated glucose utilisation index in individual tissues was measured by the 2-deoxy-[1-3 $\left.{ }^{3} \mathrm{H}\right]$-glucose technique. The effect of neuropeptide $\mathrm{Y}$ on insulin secretion was evaluated by hyperglycaemic clamp. Infusion did not induce any change in endogenous glucose production during basal conditions or at the end of the clamp. Glucose disposal was significantly increased in the rats given neuropeptide $\mathrm{Y}$ compared with controls $\left(27.8 \pm 1.3\right.$ vs $\left.24.3 \pm 1.6 \mathrm{mg} \cdot \mathrm{min}^{-1} \cdot \mathrm{kg}^{-1} ; p<0.05\right)$
\end{abstract}

as was the glycolytic flux $(18.9 \pm 1.6$ vs $14.4 \pm$ $\left.0.8 \mathrm{mg} \cdot \mathrm{min}^{-1} \cdot \mathrm{kg}^{-1} ; p<0.05\right)$, while glucose storage was comparable in the two groups. In skeletal muscle, the glucose utilisation index was increased significantly in rats given neuropeptide Y. The glucose utilisation index in subcutaneous and epididimal adipose tissue was not significantly different between the two groups. Plasma leptin was significantly increased by hyperinsulinaemia, but was not affected by neuropeptide $\mathrm{Y}$ infusion. Both the early and late phase of the insulin response to hyperglycaemia were significantly reduced by neuropeptide Y. In conclusion neuropeptide $\mathrm{Y}$ infusion may increase insulin-induced glucose disposal in normal rats, accelerating its utilisation through the glycolytic pathway. Neuropeptide Y reduces both phases of the insulin response to hyperglycaemia. [Diabetologia (1998) 41: 1361-1367]

Keywords Neuropeptide Y, insulin secretion, insulin sensitivity, leptin, clamp technique, rat
Neuropeptide $\mathrm{Y}$ is a potent stimulator of food intake [1-4]. It is widely distributed in the central nervous system, but at the hypothalamic level it is synthesised in the arcuate nucleus, from where it is released in the paraventricular nucleus [5]. Previous studies have shown that chronic intracerebroventricular administration of neuropeptide $\mathrm{Y}$ in normal rats increases food intake and produces a syndrome charac-

Received: 4 March 1998 and in revised form: 27 May 1998

Corresponding author: Dr. R. Vettor, Endocrine-Metabolic Laboratory, Institute of Semeiotica Medica, Via Ospedale 105, I-35 100 Padua, Italy terised by obesity, hyperinsulinaemia, increased metabolic activity of white adipose tissue and muscle insulin resistance. Several of these metabolic effects are still present when increased food intake is prevented by food restriction [3]. Hence, it is probable that neuropeptide $\mathrm{Y}$ is a major neuromodulator with a role in nutrient partitioning. Moreover the obesity syndrome produced by intracerebroventricular neuropeptide $\mathrm{Y}$ is characterised by increased expression of the $o b$ gene in adipose tissue [6]. On the other hand the $o b$ gene product, leptin, has been shown to inhibit neuropeptide $\mathrm{Y}$ synthesis and release from hypothalamic nuclei in ob/ob mice [7]. Thus, the existence of a long loop control system in 
energy metabolism has been identified between the brain and adipose tissue.

Neuropeptide $\mathrm{Y}$ is also present in circulating blood, where it comes mainly from the spillover of the sympathetic nerve terminals and from the adrenal medulla [8]. Its plasma concentrations rise in response to muscular exercise [9] and in disorders such as pheochromocytoma and renal failure [10]. Neuropeptide $\mathrm{Y}$ is present in the pancreas, in both the islet cells and in sympathetic nerve terminals $[11,12]$. However, whether peripheral neuropeptide Y has a hormone-like action and directly influences glucose metabolism and/or insulin secretion in vivo remains unclear. It should be noted in this respect that neuropeptide $\mathrm{Y}$, at high concentrations, may contribute to the modulation of insulin secretion in vitro [13, 14]. It has also been reported that neuropeptide $Y$ may reduce plasma glucose concentrations during exercise by inhibiting glycogen breakdown in the splanchnic compartment $[15,16]$. Moreover, the potential relation between circulating neuropeptide $Y$ and the pathophysiological consequences of obesity are far from clear.

This study aimed to evaluate the effects of short term intravenous neuropeptide $\mathrm{Y}$ infusion on the overall glucose disposal in vivo during euglycaemic hyperinsulinaemic clamp and to assess glucose utilisation in different tissues, using clamps associated with the labelled 2-deoxyglucose technique. The impact of neuropeptide Y on in vivo insulin secretion was evaluated during hyperglycaemic clamps. The influence of neuropeptide $Y$ on serum leptin values was also estimated during euglycaemic hyperinsulinaemic clamp.

\section{Materials and methods}

Animals. Twelve week old male Sprague Dawley rats were used throughout the study. Animals were housed in our animal quarters under conditions of controlled temperature $\left(23^{\circ} \mathrm{C}\right)$ and light ( 6 am- $6 \mathrm{pm})$, and had free access to water and a standard laboratory chow (Zoopharma, Padua, Italy). The protocol was approved by an internal ethics committee and experiments were performed in agreement with the rules of the laboratory animal care and the Italian law on animal experimentation.

Surgical procedure. After an overnight fast, rats were anaesthetised by intraperitoneal injection of pentobarbital $(50 \mathrm{mg} /$ $\mathrm{kg}$ ). Two indwelling catheters were inserted - one in the right jugular vein for infusion of glucose, insulin and tracers and the other in the left carotid artery for blood sampling, as previously described in details [17]. Body temperature was maintained at $37^{\circ} \mathrm{C}$ throughout the study by means of a heating blanket connected to a rectal probe.

Euglycaemic-hyperinsulinaemic clamp and glucose turnover rate. To evaluate the effects of the peripheral neuropeptide $\mathrm{Y}$ infusion on the glucose disappearance rate, endogenous glucose production and glycolytic flux in 12 rats, a 30 min recovery period from surgery was followed by a primed-continuous $3{ }^{3} \mathrm{H}$-glucose infusion $\left(0.15 \mu \mathrm{Ci} \cdot \mathrm{min}^{-1}\right)$ to reach a steady state of glucose tracer after $30 \mathrm{~min}$ [18]. In six rats, a primed-continuous infusion of neuropeptide $\mathrm{Y}\left(60 \mathrm{pmol} \cdot \mathrm{min}^{-1} \cdot \mathrm{kg}^{-1}\right)$ was then started and was continued throughout the study to reach a stable increase in plasma neuropeptide $\mathrm{Y}$ concentrations. Starting $30 \mathrm{~min}$ after the neuropeptide Y infusion (time 0), a human insulin solution (Actrapid, Novo, Bagsvaerd, Denmark) was infused at a rate of $15 \mathrm{mIU} \cdot \mathrm{min}^{-1} \cdot \mathrm{kg}^{-1}$ together with a $20 \%$ glucose solution, to maintain the arterial plasma glucose concentrations at the euglycaemic values.

Arterial blood samples $(200 \mu \mathrm{l})$ were collected before the tracer infusion (at time $-60 \mathrm{~min}$ ), $30 \mathrm{~min}$ after neuropeptide $\mathrm{Y}$ infusion (time $0 \mathrm{~min}$ ) and at the end of the clamp (time $120 \mathrm{~min}$ ) to measure glucose, insulin and lactate concentrations. Small aliquots $(30 \mu \mathrm{l})$ of blood were taken every 5-10 min during the clamp for the measurement of plasma glucose. In addition, samples $(50 \mu \mathrm{l})$ were collected at times $-30,0$ and every $10 \mathrm{~min}$ during the last $60 \mathrm{~min}$ of the clamp, by which time a constant glucose infusion rate and plasma glucose specific activity had been reached for determination of plasma radioactivity. Samples of arterial blood $(50 \mu \mathrm{l})$ were precipitated in $250 \mu \mathrm{l} \mathrm{ZnSO}_{4}$ and $250 \mu \mathrm{l} \mathrm{Ba}(\mathrm{OH})_{2}$ and centrifuged immediately. Aliquots of the supernatant were used to measure the glucose concentration and $3-{ }^{3} \mathrm{H}$-glucose radioactivity. Glucose turnover and endogenous glucose production were calculated in the basal state, after $30 \mathrm{~min}$ of neuropeptide Y infusion and in the insulin-stimulated state, as described previously [17]. Glycolytic flux and glucose storage were calculated as described by Rossetti and Giaccari [19] and reported previously by our laboratory [18].

Measurement of tissue glucose utilisation index. Two groups of six rats were used to assess the effect of peripheral neuropeptide $\mathrm{Y}$ infusion on glucose utilisation by individual tissues. A primed continuous infusion of neuropeptide $\mathrm{Y}$ (60 $\mathrm{pmol} \cdot \mathrm{min}^{-1} \cdot \mathrm{kg}^{-1}$ ) or saline was started at the end of the recovery period and continued throughout the experiment. After 30 min (time 0), insulin and a glucose solution were infused as described above to reach a new euglyaemic-hyperinsulinaemic steady state. When the latter was reached (after about $70-90 \mathrm{~min}$ ), a bolus of 2 -deoxy- $\left[1-{ }^{3} \mathrm{H}\right]$-glucose (2DG, $\left.30 \mu \mathrm{Ci}\right)$ was injected through the jugular vein and arterial samples $(50 \mu \mathrm{l})$ were collected for blood 2-deoxyglucose specific activity at times 1, 3, 5, 10, 20, 30 min after the 2DG injection. Aliquots of arterial plasma were collected at times -30 and $0 \mathrm{~min}$, and at the end of clamp for determination of plasma insulin, glucose, non-esterified fatty acid, lactate, and neuropeptide Y concentrations. Thirty minutes after the 2DG injection, the animals were killed and tissues were collected for the determination of the 2DG and 2DG6P content. The following tissues were collected: diaphragm, white and red quadriceps, white and red gastrocnemius, epidydimal and subcutaneous adipose tissue. The 2DG and 2DG6P contents were measured as described previously [20].

Hyperglycemic clamp. To study the effect of neuropeptide Y infusion on insulin secretion, hyperglycaemic clamp studies were carried out as previously described in rats [17]. The surgical procedure was the same as above. After 30 min of recovery from surgery, an infusion of saline or neuropeptide $Y(60$ $\mathrm{pmol} \cdot \mathrm{min}^{-1} \cdot \mathrm{kg}^{-1}$ ) was started in two groups of six animals and continued throughout the experiments. After $30 \mathrm{~min}$ (time $0 \mathrm{~min}$ ), a $20 \%$ glucose solution was infused at a rate of $70,57,46,35$ and $25 \mathrm{mg} \cdot \mathrm{min}^{-1} \cdot \mathrm{kg}^{-1}$ at times $0,1,2,3,4$ and 5 min respectively. The glucose infusion rate was monitored via plasma glucose concentrations to obtain clamps at $13-13.5 \mathrm{mmol} / \mathrm{l}$ (coefficient of variance $<10 \%$ ). Blood samples $(30 \mu \mathrm{l})$ for glucose assay were collected at times -30 and 
Table 1. Biochemical and hormonal profile of control rats $(n=6)$ and rats given neuropeptide Y infusion $(n=6)$ in basal conditions, after $30 \mathrm{~min}$ of saline or neuropeptide Y infusion and at the end of euglycaemic hyperinsulinaemic clamp

\begin{tabular}{|c|c|c|c|c|c|c|}
\hline $\begin{array}{l}\text { Time/ } \\
\text { Group }\end{array}$ & $\begin{array}{l}\text { Leptin } \\
\left(\mathrm{ng} \cdot \mathrm{ml}^{-1}\right)\end{array}$ & $\begin{array}{l}\text { Neuropeptide } Y \\
\left(\mathrm{ng} \cdot \mathrm{ml}^{-1}\right)\end{array}$ & $\begin{array}{l}\text { Glucose } \\
\left(\mathrm{mmol} \cdot \mathrm{l}^{-1}\right)\end{array}$ & $\begin{array}{l}\text { Insulin } \\
\left(\mu \mathrm{UI} \cdot \mathrm{ml}^{-1}\right)\end{array}$ & $\begin{array}{l}\text { Lactate } \\
\left(\mathrm{mmol} \cdot 1^{-1}\right)\end{array}$ & $\begin{array}{l}\text { Non-esterified } \\
\text { fatty acid } \\
\left(\mu \mathrm{mol} \cdot \mathrm{l}^{-1}\right)\end{array}$ \\
\hline $\begin{array}{l}\text { Baseline } \\
\text { Control } \\
\text { neuropeptide Y }\end{array}$ & $\begin{array}{l}0.49 \pm 0.11 \\
0.63 \pm 0.08\end{array}$ & $\begin{array}{l}2.8 \pm 0.3 \\
2.6 \pm 0.8\end{array}$ & $\begin{array}{l}6.1 \pm 0.3 \\
6.4 \pm 0.2\end{array}$ & $\begin{array}{l}24 \pm 12 \\
30 \pm 10\end{array}$ & $\begin{array}{l}0.95 \pm 0.21 \\
0.80 \pm 0.10\end{array}$ & $\begin{array}{l}792 \pm 76 \\
629 \pm 62\end{array}$ \\
\hline $\begin{array}{l}30 \text { min after salir } \\
\text { Control } \\
\text { neuropeptide Y }\end{array}$ & $\begin{array}{c}\text { europeptide } \\
0.58 \pm 0.16 \\
0.69 \pm 0.10\end{array}$ & $\begin{array}{l}\text { ion } \\
2.3 \pm 0.4 \\
7.1 \pm 1.3^{\mathrm{a}}\end{array}$ & $\begin{array}{l}5.5 \pm 0.4 \\
6.3 \pm 0.3\end{array}$ & $\begin{array}{l}30 \pm 10 \\
28 \pm 8\end{array}$ & $\begin{array}{l}1.02 \pm 0.08 \\
0.89 \pm 0.05\end{array}$ & $\begin{array}{l}825 \pm 77 \\
731 \pm 41\end{array}$ \\
\hline $\begin{array}{l}\text { End of clamp } \\
\text { Control } \\
\text { neuropeptide Y }\end{array}$ & $\begin{array}{l}1.15 \pm 0.10^{\mathrm{b}} \\
1.41 \pm 0.22^{\mathrm{b}}\end{array}$ & $\begin{array}{c}2.5 \pm 0.8 \\
10.1 \pm 1.8^{\mathrm{a}, \mathrm{b}}\end{array}$ & $\begin{array}{l}6.1 \pm 0.2 \\
6.1 \pm 0.2\end{array}$ & $\begin{array}{l}121 \pm 16^{b} \\
137 \pm 9^{b}\end{array}$ & $\begin{array}{l}1.47 \pm 0.09^{\mathrm{b}} \\
1.09 \pm 0.06^{\mathrm{a}}\end{array}$ & $\begin{array}{l}269 \pm 39 \\
260 \pm 41\end{array}$ \\
\hline
\end{tabular}

Mean \pm SE

Statistical analysis performed by ANOVA.

${ }^{\mathrm{a}} p \leq 0.05$ compared with control group; ${ }^{\mathrm{b}} p \leq 0.05$ compared with baseline value

Table 2. Parameters of glucose metabolism assessed during basal conditions, after 30 min of saline $(n=6)$ or neuropeptide Y $(n=6)$ infusion and at the end of euglycaemic hyperinsulinaemic clamp

\begin{tabular}{|c|c|c|c|c|}
\hline Time/group & $\begin{array}{l}\text { Endogenous glucose } \\
\text { production } \\
\left(\mathrm{mg} \cdot \mathrm{kg}^{-1} \cdot \mathrm{min}^{-1}\right)\end{array}$ & $\begin{array}{l}\text { Glucose disappearance } \\
\text { rate }(\mathrm{M})^{*} \\
\left(\mathrm{mg} \cdot \mathrm{kg}^{-1} \cdot \mathrm{min}^{-1}\right)\end{array}$ & $\begin{array}{l}\text { Glycolytic flux } \\
\left(\mathrm{mg} \cdot \mathrm{kg}^{-1} \cdot \mathrm{min}^{-1}\right)\end{array}$ & $\begin{array}{l}\text { Glucose storage } \\
\left(\mathrm{mg} \cdot \mathrm{kg}^{-1} \cdot \mathrm{min}^{-1}\right)\end{array}$ \\
\hline $\begin{array}{l}\text { Basal } \\
\text { Control } \\
\text { neuropeptide Y }\end{array}$ & $\begin{array}{l}12.8 \pm 1.5 \\
13.6 \pm 0.6\end{array}$ & $\begin{array}{l}12.8 \pm 1.5 \\
13.6 \pm 0.6\end{array}$ & $\begin{array}{l}- \\
-\end{array}$ & $\begin{array}{l}- \\
-\end{array}$ \\
\hline $\begin{array}{l}30 \text { min after salin } \\
\text { Control } \\
\text { neuropeptide } Y\end{array}$ & $\begin{array}{l}\text { eptide Y infusion } \\
11.0 \pm 1.7 \\
11.9 \pm 0.5\end{array}$ & $\begin{array}{l}11.0 \pm 1.7 \\
11.9 \pm 0.5\end{array}$ & $\begin{array}{l}- \\
-\end{array}$ & $\begin{array}{l}- \\
-\end{array}$ \\
\hline $\begin{array}{l}\text { End of clamp } \\
\text { Control } \\
\text { neuropeptide Y }\end{array}$ & $\begin{array}{l}0.67 \pm 0.95^{\mathrm{b}} \\
0.81 \pm 0.33^{\mathrm{b}}\end{array}$ & $\begin{array}{l}24.3 \pm 1.6^{\mathrm{b}} \\
27.8 \pm 1.3^{\mathrm{a}, \mathrm{b}}\end{array}$ & $\begin{array}{l}14.4 \pm 0.8 \\
18.9 \pm 1.6^{\mathrm{a}}\end{array}$ & $\begin{array}{l}9.8 \pm 0.7 \\
9.2 \pm 2.1\end{array}$ \\
\hline
\end{tabular}

Mean \pm SE

* See calculation section for details

Statistical analysis performed by ANOVA

${ }^{\mathrm{a}} p<0.05$ compared with control group. ${ }^{\mathrm{b}} p<0.05$ compared with baseline value

$0 \mathrm{~min}$, at $1 \mathrm{~min}$ intervals during the first $7 \mathrm{~min}$ and then every 5-10 min. Blood samples for insulin determination were collected at times -30 and 0 min to assess basal insulinaemia, at times $1,2,3,4,5,6,7$ and $10 \mathrm{~min}$ to assess early insulin response to hyperglycaemia and then at 10 min intervals to evaluate late insulin response. The experiments were stopped at time 120 min. During hyperglycaemic clamp, endogenous glucose production, is completely suppressed [21], and glucose disposal was determined as described in the calculations section. Early (0-10 $\mathrm{min})$, late (10-90 $\mathrm{min})$ and total (0-90 min) insulin responses were calculated as the area under the curve of the plasma insulin concentration during each time interval.

Effects of neuropeptide $Y$ on systemic haemodynamics. In a separate experiment, four rats were anaesthetised with pentobarbital and prepared as previously described [22]. Mean arterial pressure and heart rate were determined by a microcomputer system (Cardiomax IIR, Columbus Instruments, Columbus, Ohio, USA) and recorded in a multichannel system (MX4P and MT4, Lectromed Ltd., Jersey, Channel Islands, UK). After baseline determination of arterial pressure and heart rates, animals received an intravenous infusion of neuropeptide $\mathrm{Y}$ at the same dose as in the clamp studies.
Reagents and analytical procedures. Human neuropeptide $\mathrm{Y}$ was purchased from Inalco (Milan, Italy), dissolved in citrate buffer and stored at $-80^{\circ} \mathrm{C}$. The solution was then diluted in phosphate buffer for the experiments. $3-{ }^{3} \mathrm{H}$-glucose and 2deoxy $\left[1-{ }^{3} \mathrm{H}\right]$-glucose were purchased from Amersham (High Wycombe, England). Plasma glucose was determined by the glucose oxidase method (Glucose Analyzer 2, Beckman, Beckman Instruments, Palo Alto, Calif., USA). Lactate and free fatty acids were measured using commercial kits (Boehringer Mannheim, Mannheim, Germany), with enzymatic spectrophotometric techniques. Insulin was measured with a radioimmunoassay, using rat and human insulin as standards. Neuropeptide $\mathrm{Y}$ was measured by enzyme-immunoassay using a commercial kit (Peninsula, San Careos, Calif., USA). Plasma leptin was measured by a specific radioimmunoassay previously described in detail [23].

Calculations and statistical analysis. Glucose turnover in basal and clamp conditions was calculated as the ratio between the tracer infusion rate $\left(\mathrm{dpm} \cdot \mathrm{min}^{-1}\right)$ and glucose specific activity $\left(\mathrm{dpm} \cdot \mathrm{mg}^{-1}\right)$. Glucose uninary losses were measured and found to be negligible, and glucose space corrections due to changes in glucose concentration during the euglycaemic clamp were trivial. Endogenous glucose production was calcu- 
lated as the difference between glucose disappearance and the exogenous glucose infusion rate. The rate of whole body glucose disposal $(\mathrm{M})$ was derived from the equation $\mathrm{M}=\mathrm{GIR}$ $\mathrm{SpC}-\mathrm{UrL}$, where GIR is exogenous glucose infusion rate, $\mathrm{SpC}$ is the space correction during the last $20 \mathrm{~min}$ of clamp due to over- or underfilling of the glucose space and UrL is the glucose urinary loss during the study. Under hyperglycaemic clamp conditions the whole body glucose disposal was considered equal to the glucose infusion rate at steady state hyperglycaemia.

All data are expressed as the mean \pm SE values. Statistical analysis was performed using the one way analysis of variance (ANOVA).

\section{Results}

Biochemical profiles in basal and insulin-stimulated conditions are summarised in Table 1 . In the basal state, no difference was found between the control and neuropeptide Y-infused group in relation to the lactate, non-esterified fatty acid or insulin values. The rise in plasma lactate that was clearly evident during hyperinsulinaemia in control animals was suppressed in rats given neuropeptide $Y(1.47 \pm 0.09$ vs $1.09 \pm 0.06 \mathrm{mmol} / \mathrm{l} ; p<0.01)$. Plasma non-esterified fatty acids were similarly suppressed in both groups during hyperinsulinaemia ( $269 \pm 39$ vs $260 \pm 41 \mu \mathrm{mol} /$ 1). Neuropeptide Y values were comparable in the basal state and remained essentially constant in the control experiments while being increased about fourfold in animals given neuropeptide $\mathrm{Y}$ infusion.

Parameters of basal and insulin-stimulated glucose metabolism are summarised in Table 2. Endogenous glucose production during basal conditions was not significantly different in the two groups of animals and was not significantly modified by a $30 \mathrm{~min}$ infusion of saline or neuropeptide $\mathrm{Y}(11.0 \pm 1.7$ vs $11.9 \pm 0.5 \mathrm{mg} \cdot \mathrm{min}^{-1} \cdot \mathrm{kg}^{-1}$, NS). In addition endogenous glucose production at the end of the clamp was suppressed similarly in both groups (Table 2). As further shown by Table 2, glucose disposal at the end of clamp was higher in rats infused with neuropeptide $\mathrm{Y}$ than controls. Whole body glycolytic flux was increased to the same extent as total glucose disposal in the neuropeptide Y-infused group, while no significant difference was observed in glucose storage. The glucose utilisation index, measured $30 \mathrm{~min}$ after a bolus injection of $2 \mathrm{DG}$, was not significantly different between the two groups in subcutaneous adipose tissue and in visceral adipose tissue (Fig.1). However, in most skeletal muscles studied, there was an increase in the insulin-stimulated glucose utilisation index in the neuropeptide Y-infused group compared to controls (Fig. 1). Plasma leptin under basal conditions was $0.49 \pm 0.11$ and $0.63 \pm 0.08 \mathrm{ng} / \mathrm{ml}$ in control and neuropeptide Y-infused rats respectively (NS). The plasma leptin concentration was increased comparably by the euglycaemic-hyperinsulinaemic clamps in

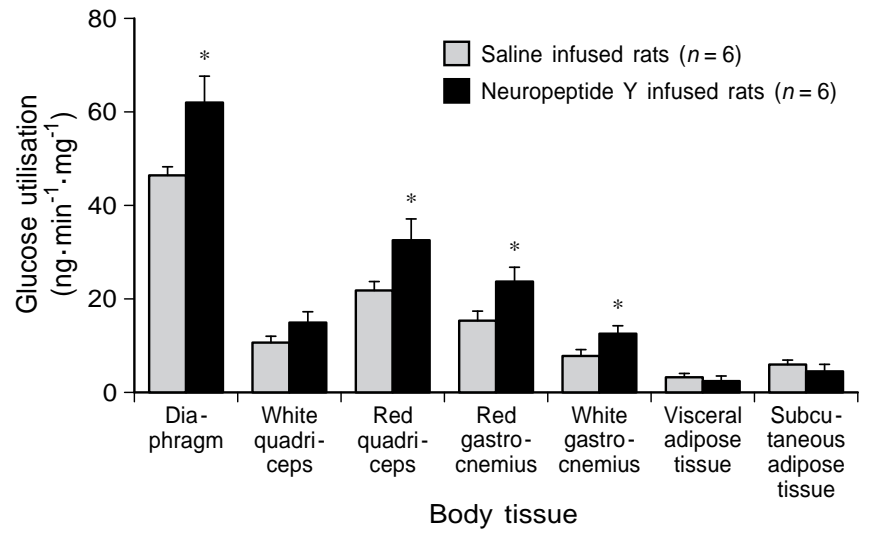

Fig.1. Glucose utilisation index (euglycaemic-hyperinsulinaemic clamps associated with the labeled 2-deoxyglucose technique, see Methods) by muscles of control and neuropeptide Y-infused rats. Values are mean \pm SE. Statistical analysis performed by ANOVA * $p<0.05$ at least

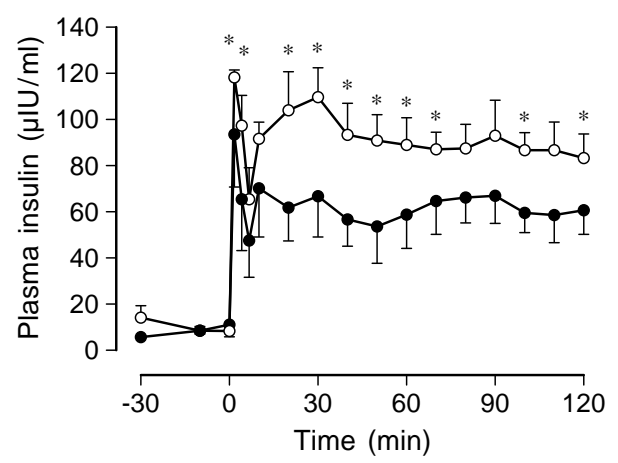

Fig. 2. Insulin output during in vivo glucose-elicited hyperglycaemic clamps in control rats (open circles, $n=6$ ) and neuropeptide Y-infused (closed circles, $n=6$ ) rats. Early insulin, late insulin and total insulin responses for control and neuropeptide Y-infused rats respectively were $496 \pm 56$ vs $321 \pm$ $79 \mu \mathrm{U} \cdot \mathrm{ml}^{-1} \cdot 10 \mathrm{~min}^{-1}, \quad p<0.05 ; \quad 10400 \pm 754$ vs $6274 \pm$ $1255 \mu \mathrm{U} \cdot \mathrm{ml}^{-1} \cdot 110 \mathrm{~min}^{-1}, p<0.05$ and $10896 \pm 782$ vs $6595 \pm$ $1329 \mu \mathrm{U} \cdot \mathrm{ml}^{-1} \cdot 120 \mathrm{~min}^{-1}, p<0.05$. Values are mean $\pm \mathrm{SE}$

control and NPY-infused rats (intergroup differences, NS, differences from baseline values, $p<0.01$ by ANOVA).

In vivo insulin output and the total rate of glucose disposal were measured during hyperglycaemic clamps. Upon doing so, plasma glucose was increased from baseline values to values of $13-13.5 \mathrm{mmol} / \mathrm{l}$ in both groups of animals. Total glucose disposal during hyperglycaemic clamps, measured in the last $30 \mathrm{~min}$ of the study, was unchanged by neuropeptide Y infusion, as was the glucose clearance rate (Table 3). Basal insulin concentrations and the insulin response to hyperglycaemia are depicted in Fig. 2. Neuropeptide Y treatment inhibited both the early and late insulin responses to hyperglycaemia, with the result that total insulin response was also inhibited.

Infusion of neuropeptide $\mathrm{Y}$ did not change the mean blood pressure $(130.6 \pm 3.2$ vs $131.1 \pm$ 
Table 3. Biochemical profiles and parameters of glucose metabolism as assessed at the end of hyperglycaemic clamp in saline $(n=6)$ and neuropeptide $\mathrm{Y}(n=6)$ infused animals

\begin{tabular}{lllll}
\hline Group & Lactate $\mathrm{mmol} \cdot \mathrm{l}^{-1}$ & $\begin{array}{l}\text { Non-esterified fatty acid } \\
\left(\mu \mathrm{mol} \cdot \mathrm{l}^{-1}\right)\end{array}$ & $\begin{array}{l}\text { Glucose disappearance } \\
\text { rate }(\mathrm{M}) *\left(\mathrm{mg}^{-1} \mathrm{~kg}^{-1} \cdot \mathrm{min}^{-1}\right)\end{array}$ & $\begin{array}{l}\text { Glucose clearance } \\
\left(\mathrm{ml} \cdot \mathrm{kg}^{-1} \cdot \mathrm{min}^{-1}\right)\end{array}$ \\
\hline Control & $2.34 \pm 0.37$ & $558 \pm 59$ & $19.8 \pm 1.7$ & $7.98 \pm 0.64$ \\
Neuropeptide Y & $2.67 \pm 0.42$ & $442 \pm 62$ & $18.1 \pm 2.5$ & $7.20 \pm 1.05$ \\
\hline
\end{tabular}

Mean \pm SE

* See calculation section for details

$3.8 \mathrm{mmHg}$ for control and treatment groups respectively) or heart rate $(412 \pm 15$ vs $423 \pm 17 \mathrm{bpm})$ from baseline values.

\section{Discussion}

In the present experiments, infusion of neuropeptide $\mathrm{Y}$ in overnight fasted rats lead to a fourfold increase in the arterial concentration of neuropeptide $\mathrm{Y}$ that remained constant throughout the clamp study. A similar increase in the plasma neuropeptide $\mathrm{Y}$ concentrations has been reported during muscular exercise or in stressful situations in both animals and humans [24-26].

In this study, hepatic glucose production in both basal conditions and at the end of clamp, was not influenced by intravenous neuropeptide $\mathrm{Y}$ infusion. A normal insulin sensitivity in suppressing hepatic glucose production was observed in both control and neuropeptide Y-infused rats. However, peripheral glucose disposal, as assessed by the clamp technique, was increased appreciably by neuropeptide $\mathrm{Y}$ infusion, suggesting that this peptide affected glucose uptake and utilisation by increasing their responsiveness to insulin. We cannot exclude the possibility that a longer infusion of neuropeptide $\mathrm{Y}$ in basal conditions would modify glucose turnover and insulin sensitivity. The predominant site of insulin-mediated whole body glucose disposal in vivo was found to be skeletal muscle. Indeed, the glucose utilisation index determined in a wide range of skeletal muscle groups comprising white, mostly red, and mixed muscle fibres was shown to be increased by neuropeptide $\mathrm{Y}$ infusion. It was observed, concomitantly that neuropeptide $\mathrm{Y}$ increased the glycolytic flux, while the rate of glucose storage remained unaffected. This observation suggests that neuropeptide $\mathrm{Y}$ infusion may result in direct or indirect activation not only of glucose uptake and phosphorylation but in the acceleration of some glycolytic enzyme activity at the site.

The plasma lactate concentration increased during euglycaemic hyperinsulinaemic clamps, presumably as a result of an increased glycolytic flux. During neuropeptide $\mathrm{Y}$ infusion, the rise in blood lactate was blunted. The present results do not allow any conclusion about the effect of neuropeptide Y on lactate metabolism, but we suggest that the neuropeptide may accelerate oxidative pathways, particularly at the level of the liver [16], thereby reducing lactate production.

In the present study, neuropeptide $\mathrm{Y}$ infusion failed to affect insulin-mediated glucose utilisation by white adipose tissue. This is in keeping with the lack of receptors specific to neuropeptide Y in rat adipocytes or with a low binding affinity as shown in adipocytes from dogs and humans in which neuropeptide $\mathrm{Y}$ displays a very weak antilypolitic effect [27, 28].

The effect of neuropeptide Y on muscular glucose metabolism may be a direct one or it may be mediated by other factors, since there is no evidence for the existence of neuropeptide $Y$ receptors in skeletal muscle cells. On the other hand, specific $\mathrm{Y}_{1}$ receptor subtypes have been identified in vascular cells of skeletal muscle in the pig [29], and there is increasing evidence, in both animals and humans, that neuropeptide Y may represent the non-adrenergic constrictory component that influences appreciably local blood flow in several tissues, including skeletal muscles [30,31].

In our experiments, we did not measure regional haemodynamic responses to neuropeptide Y, but infusion did not modify either the heart rate or arterial blood pressure, suggesting that, at the doses used, neuropeptide Y had no cardiovascular effect in anaesthetised animals. The lack of effect on the systemic blood pressure and heart rate does not exclude the possibility that local neuropeptide $Y$ effects may induce changes in regional blood flow, as previously described [32]. However, we have to consider that if the main haemodynamic effect of neuropeptide $\mathrm{Y}$ in the skeletal muscle vascular bed was a reduction in blood flow, the insulin and fuel supply to the cells would be reduced, resulting in reduced glucose utilisation. This is not the case in our experiments, in which neuropeptide $\mathrm{Y}$ has opposite effects, thus re-enforcing the conclusion of a genuine effect independent of changes in blood flow. In any case, we cannot exclude the possibility that the effect on glucose metabolism is mediated centrally since leakage through the blood brain barrier has been reported [33].

Our study also shows the effect of neuropeptide $Y$ on insulin secretion kinetics as assessed during hyperglycaemic clamps. Intravenous neuropeptide Y inhibited both the early and the late phase of insulin response. It is noteworthy that this effect is evident at concentrations appreciably lower than those reported 
to inhibit insulin release in in vitro studies $[14,34,35]$. In mouse pancreas neuropeptide Y mRNA is present in the islets of Langerhans at the same site as glucagon within the alpha-cells $[36,37]$. Moreover a nervous network rich in neuropeptide $\mathrm{Y}$ as well as sympathetic nerve endings containing the peptide have been found in the endocrine portion of the pancreas [38], suggesting that neuropeptide $\mathrm{Y}$ has a role in the neural regulation of islet function as a mediator of sympathetic nervous system induced inhibition of insulin secretion.

Our results are consistent with findings from previous in vitro studies indicating that neuropeptide $Y$ has a prevalent inhibitory effect on insulin secretion $[14,34,35]$. This suggests that neuropeptide $Y$ may inhibit insulin secretion by a direct pancreatic action. However, in vivo studies of the affects of neuropeptide Y on insulin output have often given contradictory results. In rats, intravenous neuropeptide Y stimulated basal insulin secretion in vivo, while inhibiting glucose-induced insulin secretion [39]. Moreover, in dogs, the pancreatic administration of neuropeptide $Y$ resulted in a slight stimulatory effect [40].

Given the vasocontrictory effect of neuropeptide $\mathrm{Y}$, regional reduction in blood flow could justify a reduced pancreatic hormone production in keeping with other data that showed a reduction in pancreatic flow and insulin secretion with neuropeptide $Y$ in pigs [41] and in perfused rat pancreas [42]. In our protocol, we observed no change in arterial blood pressure and heart rate, suggesting that another mechanism must underly the effect of neuropeptide $\mathrm{Y}$ on insulin output. It is well known that norepinephrine is a powerful inhibitor of insulin secretion and neuropeptide $\mathrm{Y}$ influences the sympathetic tone [43]. Thus, neuropeptide Y may exert its inhibitory role on insulin secretion indirectly through its action on norepinephrine, rather than directly.

We have previously observed that long term intracerebroventricular neuropeptide $\mathrm{Y}$ administration in rats induces a syndrome characterised by increased food intake, obesity, hyperinsulinaemia, muscle insulin resistance and an increased metabolic activity in white adipose tissue [1-3]. It has been widely recognised that $o b$ gene expression and leptin release by adipose tissue are under neuroendocrine influence, and it has been shown that intracerebroventricular neuropeptide Y infusion also increases $o b$ gene expression [6] and its product, which may in turn inhibit neuropeptide $\mathrm{Y}$ at the central nervous system level [7]. Furthermore, leptin expression and production by adipose tissue are regulated by factors influencing glucose metabolism, such as insulin and glucocorticoids. In particular, insulin rapidly regulates $o b$ gene transcription, enhancing circulating leptin in rats [23, $44,45]$. In our experiments, we observed that continuous intravenous infusion of insulin during euglycaemic clamp produced a significant increase in serum leptin, as reported previously [23]. Moreover the intravenous infusion of neuropeptide $\mathrm{Y}$ did not induce any change in leptin concentrations, either in basal conditions or during euglycaemic hyperinsulinaemia. In addition, intracerebroventricular neuropeptide $\mathrm{Y}$ has been shown to potentiate the insulinaemic response to intravenous glucose, while reducing the ability of insulin to control glucose metabolism and, in particular, to suppress glucose production $[46,47]$.

In conclusion, the major new finding of this study is the observation that peripheral neuropeptide $\mathrm{Y}$ infusion in normal rats increases the overall rate of glucose disposal by increasing insulin responsiveness in skeletal muscle. Moreover, the increased glycolytic flux combined with the blunted increase in lactate suggests that neuropeptide $\mathrm{Y}$ may raise insulin mediated glucose disposal by increasing its utilisation through the oxidative pathways. Further in vitro studies are required to confirm this hypothesis. Intravenous neuropeptide $\mathrm{Y}$ does not influence glucose metabolism in adipose tissue and leptin release. Peripheral neuropeptide $\mathrm{Y}$ plays a clear inhibitory role in glucose-induced insulin secretion. These data indicate that neuropeptide $\mathrm{Y}$ has different effects on insulin secretion when administered acutely via intracerebroventricular or intravenous routes. In addition, the effects on peripheral and hepatic glucose metabolism are different between these routes, but it is possible that the duration of treatment, and not just the route of administration, may be a relevant factor.

Acknowledgements. This work was supported by a grant from the Italian MURST (Ministero della Ricerca Scientifica e Tecnologica). Expert technical assistance of Mrs Marilena Tormene and Mrs Sonia Leandri is gratefully acknowledged.

\section{References}

1. Vettor R, Zarjevski N, Cusin I, Rohner-Jeanrenaud F, Jeanrenaud B (1994) Induction and reversibility of an obesity syndrome by intracerebroventricular neuropeptide $\mathrm{Y}$ administration to normal rats. Diabetologia 37: 1202-1208

2. Zarjevski N, Vettor R, Cusin I, Rohner-Jeanrenaud F, Jeanrenaud B (1994) Intracerebroventricular administration of neuropeptide $\mathrm{Y}$ to normal rats has divergent effects on glucose utilization by adipose tissue and skeletal muscle. Diabetes 43: 764-769

3. Zarjevski N, Cusin I, Vettor R, Rohner-Jeanrenaud F, Jeanrenaud B (1993) Chronic intracerebroventricular neuropeptide administration to normal rats mimics hormonal and metabolic changes of obesity. Endocrinology 133: 1753-1758

4. VanDijk G, Bottone AE, Strubbe JH, Steffens AB (1994) Hormonal and metabolic effects of paraventricular hypothalamic administration of neuropeptide Y during rest and refeeding. Brain Res 660: 96-103

5. Abe M, Saito M, Ikeda H, Shimazu T (1991) Increased neuropeptide Y content in the arcuato-paraventricular hypothalamic neuronal system in both insulin-dependent and non-insulindependent diabetic rats. Brain Res 539: 223-227

6. Sainsbury A, Cusin I, Doyle P, Rohner-Jeanrenaud F, Jeanrenaud B (1996) Intracerebroventricular administration of neuropeptide $\mathrm{Y}$ to normal rats increases obese gene expression in white adipose tissue. Diabetologia 39: 353-356 
7. Stephens TW, Basinski M, Bristow PK et al. (1995) The role of neuropeptide $\mathrm{Y}$ in the antiobesity action of the obese gene product. Nature 377: 530-532

8. Taborsky GJ, Beltramini LM, Brown M, Veith RC, Kowalyk S (1994) Canine liver releases neuropeptide Y during sympathetic nerve stimulation. Am J Physiol 266:E804-E812

9. Sundkvist G, Bramnert M, Bergstrom B, Manhem P, Lilja B, Ahren B (1992) Plasma neuropeptide Y (NPY) and galanin before and during exercise in type 1 diabetic patients with autonomic disfunction. Diabetes Res Clin Pract 15: 219-226

10. Takahashi K, Mouri T, Itoi K, Sone M, Ohneda M, Murakami O, Nozuki M, Tachibana Y, Yoshinaga K (1987) Increased plasma immunoreactive neuropeptide $\mathrm{Y}$ concentrations in phaeochromocytoma and chronic renal failure. J Hypertens 5: 749-753

11. Sundler F, Ekblad E, Hakanson R (1991) The neuroendocrine system of the gut - an update Acta Oncol 30: 419-427

12. Pettersson M, Ahren B, Lundquist I, Bottcher G, Sundler F (1987) Neuropeptide Y: intrapancreatic neuronal localization and effects on insulin secretion in the mouse. Cell Tissue Res 248: 43-48

13. Petterson M, Ahren B (1990) Insulin secretion in rats: effects of neuropeptide Y and noradrenaline. Diabetes Res 13: 35-42

14. Wang ZL, Bennet WM, Wang RM, Ghatei MA (1994) Evidence of a paracrine role of neuropeptide $\mathrm{Y}$ in the regulation of insulin release from pancreatic islets of normal and dexamethasone rats. Endocrinology 135: 200-206

15. Ahlborg G, Lundberg JM (1994) Inhibitory effects of neuropeptide on splanchnic glycogenolysis and renin release in humans. Clin Physiol 14: 187-196

16. Ahlborg G, Weitzberg E, Sollevi A, Lundberg JM (1992) Splanchnic and renal vasoconstrictor and metabolic responses to neuropeptide $\mathrm{Y}$ in resting and exercising man. Acta Physiol Scand 145: 139-149

17. Terrettaz J, Jeanrenaud B (1983) In vivo hepatic and peripheral insulin resistance in genetically obese (fa/fa) rats. Endocrinology 112: $1346-1351$

18. Pagano C, Granzotto M, Fabris R, Serra R et al. (1997) Lactate infusion to normal rats during hyperglycemia enhances in vivo muscle glycogen synthesis. Am J Physiol 273: R2072-R2079

19. Rossetti L, Giaccari A (1990) Relative contribution of glycogen synthesis and glycolysis to insulin-mediated glucose uptake. A dose response euglycemic clamp study in normal and diabetic rats. J Clin Invest 85: 1785-1792

20. Ferré P, Leturque A, Burnol AF, Penicaud L, Girard J (1985) A method to quantify glucose utilization in vivo in skeletal mucle and white adipote tissue of the anesthetized rat. Biochem J 228: $103-110$

21. DeFronzo RA, Ferrannini E, Hendler R, Felig P, Wahren J (1983) Regulation of splanchnic and peripheral glucose uptake by insulin and hyperglycaemia. Diabetes 32: 35-45

22. Angeli P, Jemenez W, Arroyo V, Mackanzie HS, Zhang PL, Claria J, Rivera F, Brenner BM, Rodes J (1994) Renal effects of natriuretic peptide receptor blockade in cirrhotic rats woth ascites. Hepatology 20: 948-954

23. Pagano C, Englaro P, Granzotto M et al. (1997) Insulin induces rapid changes of plasma leptin in lean but not in genetically obese (fa/fa) rats. Int J Obes 21: 614-618

24. Lundberg JM, Martinsson A, Hemsen A, Theodorsson-Norheim E, Svedenhag J, Ekblom B, Hjemdahl P (1985) Co-release of neuropeptide $\mathrm{Y}$ and catecholamines during physocal exercise in man. Biochem Biophys Res Commun 133: 30-36

25. Ahlborg G, Lundberg JM (1991) Splanchnic release of neuropeptide Y-like immunoreactivity and catecholamines during various degrees of sympathetic activation in man. Clin Physiol Scand 6: 561-578

26. Zukowska-Grojec Z, Konarska M, McCarty R (1988) Differential plasma catecholamine and neuropeptide $\mathrm{Y}$ responses to acute stress in rats. Life Sci 42: 1615-1624

27. Castan I, Valet F, Voisin T, Quideau N, Laburthe M, Lafontan M (1992) Identification and functional studies of a specific peptide
YY-preferring receptor in dog adipocytes Endocrinology 131: 1970-1976

28. Castan I, Valet P, Larrouy D et al. (1993) Distribution of PYY receptors in human fat cells: an antilipolytic system alongside the $\mathrm{a}_{2}$-adrenergic system. Am J Physiol 265:E74-E80

29. Modin A, Pernow J, Lundberg JM (1993) Sympathetic regulation of skeletal muscle blood flow in the pig: a non-adrenergic component likely to be mediated by neuropeptide Y. Acta Physiol Scand 148: 1-11

30. Clarke J, Beniamin N, Larkin S, Webb D, Maseri A, Davies G (1991) Interaction of neuropeptide $Y$ and the sympathetic nervous system in vascular control in man. Circulation 83: 774-777

31. Joshua IG (1991) Neuropeptide Y-induced constriction in small resistant vessels of skeletal muscle. Peptides 12: 37-41

32. Gardiner SM, Bennet T, Compton AM (1988) Regional haemodinamic effects of neuropeptide $\mathrm{Y}$, vasopressin and angiotensin II in conscious, unrestrained, Long Evand and Brattleboro rats. J Autonomic Nervous System 24: 15-27

33. Sainsbury A, Rohner-Jeanrenaud F, Grouzmann E, Jeanrenaud B (1996) Acute intracerebroventricular administration of neuropeptide Y stimulates corticosterone output and feeding but not insulin output in normal rats. Neuroendocrinology 63: 318-326

34. Alwmark A, Ahren B (1987) Phentolamine reverses NPY-induced inhibition of insulin secretion in isolated rat islets. Eur $\mathrm{J}$ Pharmacol 135: 307-311

35. Moltz JH, McDonald JK (1985) Neuropeptide Y: Direct and indirect action on insulin secretion in the rat. Peptides 6: $1155-1159$

36. Jamal H, Jones PM, Byrne J, Suda K, Ghatei MA, Kanse SM, Bloom SR (1991) Peptide contents of neuropeptide Y, vasoactive intestinal polypeptide, and b-calcitonin gene-related peptide and their messenger ribonucleic acids after dexamethasone treatment in the isolated rat islets of Langerhans. Endocrinology 129: $3372-3380$

37. Teitelman G, Alpert S, Polak JM, Martinez A, Hanahan D (1993) Precursor cells of mouse endocrine pancreas coexpress insulin, glucagon and the neural proteins tyrosine hydroxylase and neuropeptide Y, but not pancreatic polypeptide. Development 118: 1031-1039

38. Sheikh SP, Holst JJ, Skak-Nielsen T et al. (1988) Release of neuropeptide $\mathrm{Y}$ in pig pancreas: dual parasympathetic and sympathetic regulation. Am J Physiol 255:G46-G54

39. Pettersson M, Ahren B (1990) Insulin secretion in rats: effects of neuropeptide $Y$ and noradrenaline. Diabet Res 13: 35-42

40. Dunning BE, Ahren B, Bottcher G, Sundler F, Taborsky GM Jr (1987) The presence and actions of neuropeptide $Y$ in the canine endocrine pancreas. Regul Pept 18: 253-265

41. Ahren B, Martensson H, Falck B (1991) Effects of neuropeptide Yon insulin and glucagon secretion in the pig. Neuropeptides 20 : 49-55

42. Skoglund G, Gross RA, Bertrand GR, Ahren B, LoubatieresMariani MM (1991) Comparison of effects of neuropeptide $Y$ and norepinephrine on insulin secretion and vascular resistance in perfused rat pancreas. Diabetes 40: 660-665

43. Potter KE (1988) Neuropeptide Y as an autonomic neurotransmitter. Pharmacol Ther 37: 251-273

44. Cusin I, Sainsbury A, Doyle P, Rohner-Jeanrenaud F, Jeanrenaud B (1995) The ob gene and insulin. A relationship leading to clues to the understanding of obesity. Diabetes 44: 1467-1470

45. DeVos P, Saladin R, Auwerx J, Staels B (1995) Induction of ob gene expression by corticosteroids is accompanied by body weight loss and reduced food intake. J Biol Chem 270 15958-15961

46. Marks JL, Waite K (1996) Some acute effects of intracerebroventricular neuropeptide $\mathrm{Y}$ on insulin secretion and glucose metabolism in the rat. J Neuroendocrinology 8: 507-513

47. Marks JL, Waite K (1996) Intracerebroventricular neuropeptide $\mathrm{Y}$ acutely influences glucose metabolism and insulin sensitivity in the rat. J Neuroendocrinology 9: 99-103 